A s i a $\mathrm{n}$ J o u rna l of

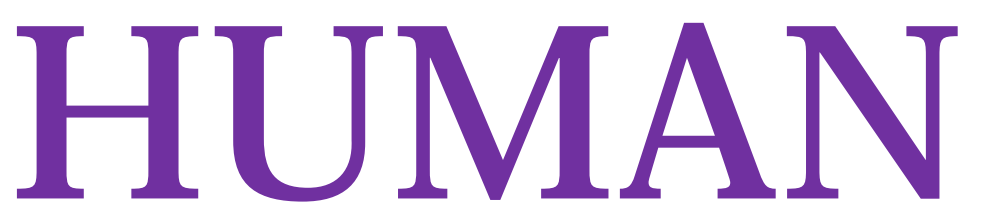

Printed 2017.1030 ISSN2188-059X

Published by Asian Society of Human Services
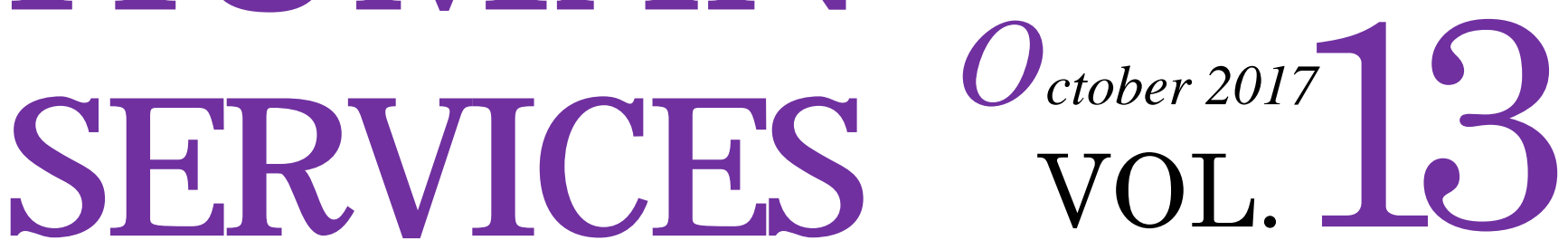

Attention Deficit

/Hyperactivity Disorder

Medical Workers

$$
\text { 舟点: }
$$

Social Services $\stackrel{\varpi}{\oplus}$ Motor and Intellectual

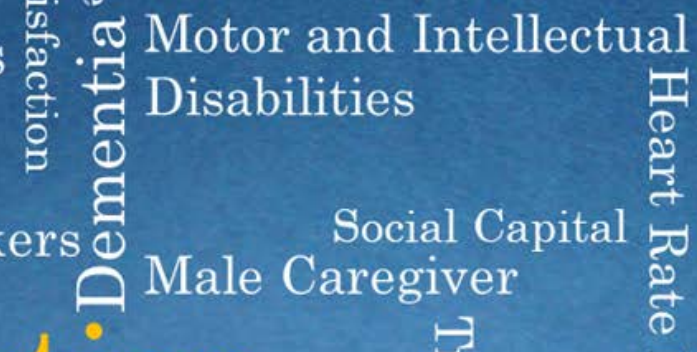

O

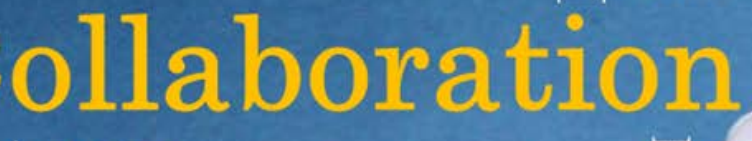

between

Medicine and Education

Neurofeedback Trainings

International Disaster Response Nursing

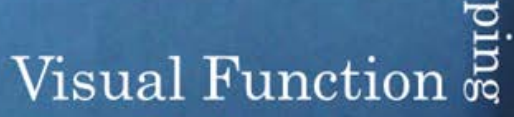

Subjective Evaluation

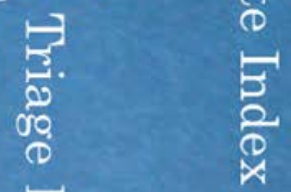

牙

Autism Spectrum

Disorder

Nursing Students Living at Home

Norms of Reciprocity

Inclusive Needs Child

Objective Evaluation 


\title{
Development of a Tool for Collaboration between the Fields of Medicine and Education Based on "Inclusive Needs-Child Record"
}

\author{
: With Focus on Autism Spectrum Disorder (ASD) and Attention \\ Deficit/Hyperactivity Disorder (ADHD)
}

\author{
1) Graduate School of Medicine, Tohoku University, Japan \\ 2) Faculty of Education, University of the Ryukyus, Japan \\ 3) Faculty of Education, University of Miyazaki, Japan
}

Natsuki $Y_{A N O}{ }^{12)}$, Haejin KWON ${ }^{3)}$, Changwan $\mathrm{HAN}^{2)}$, Masahiro KOHZUKI ${ }^{1{ }^{*}}$

Received

September 15, 2017

Revised

October 11, 2017

Accepted

October 15, 2017

Published

October 30, 2017
${ }^{*}$ Corresponding author: kohzuki@med.tohoku.ac.jp (Masahiro KOHZUKI; Japan) Asian J Human Services, 2017, 13:75-87. (C) 2017 Asian Society of Human Services 


\section{Introduction}

DSM-5 (Diagnostic and Statistical Manual of Mental Disorders, Fifth Edition) has been medically utilized to diagnose developmental disorders (American Psychiatric Association [APA], 2013). DSM-5 refers to developmental disorders as neurodevelopmental disorders with onset during the developmental period, and includes therein adaptive functional deficits in personal or social life or at school or work (APA, 2013).

Problems have arisen of late due to the limited number of medical specialists and specialized healthcare institutions that can conduct medical diagnosis of developmental disorders in Japan (Ministry of Internal Affairs and Communications [MIC], 2017). For instance, it takes 3-10 months for children to receive their first medical examination in the majority of healthcare institutions that provide developmental disorder diagnosis services. Furthermore, as the examination based on which it is determined if a child has a developmental disorder includes an in-depth investigation of the child's infanthood and growth process, the diagnosis takes 1-2 hours per patient, which limits the number of patients that can be examined in a day (MIC, 2017).

According to the Ministry of Education, Culture, Sports, Science, and Technology (MEXT), an estimated $6.5 \%$ of the children attending school may have a developmental disorder (MEXT, 2012). MEXT has recommended the utilization of the standard checklist that enables the identification of children with an early-stage developmental disorder in schools from kindergartens to high schools (MIC, 2017). If the teachers and school administrators, who spend much time with the children, can provide medical specialists with the information on such children's behaviors, it will enable the medical specialists to understand the children and to expedite the diagnosis process. Furthermore, if there are standard scales with clear criteria, teachers can observe the children more objectively and can more easily provide the objective information about them to medical specialists, making it possible for the children who have difficulties in school life to receive the proper services in a timely fashion.

In this context, Han, Ota, and Kwon (2016) have developed the Inclusive Needs-Child Record (IN-Child Record or ICR), which is useful for understanding the characteristics of students with developmental disorder tendencies. IN-Child refers to the children who need comprehensive educational support because of their problematic behavior in the classroom caused by problems related to physical or mental health, family problems, or developmental disorders (Han, Ota, \& Kwon, 2016).

The concept of IN-Child was established focusing on the educational needs of an individual child, regardless of whether the child has been diagnosed with a developmental disorder (Han, Ota, \& Kwon, 2016). Therefore, ICR is a tool that enables the comprehensive understanding of the needs of children in school (Han, Ota, \& Kwon, 2016) and can be regarded as the standard checklist recommended by MIC (2017). ICR 
consists of 82 items pertaining to education-related behavior (Han, Ota, \& Kwon, 2016), and some of these items do not need to be provided to medical specialists. As such, the necessity of coming up with a new tool that contains the items from both ICR and DSM-5 that are needed by medical specialists for diagnosing children's developmental disorders has arisen.

Therefore, this study aimed to develop a new tool that enables collaboration between the fields of medicine and education based on ICR and DSM-5, for the facilitation of the medical diagnosis of and the provision of continuous educational support for children with developmental disorders.

\section{Methods}

\section{Assessment Tool}

For this study, ICR developed by Han, Ota, and Kwon (2016) was used. ICR is a tool for assessing the needs of children classified under "IN-Child" for their comprehensive education, and for planning how to continuously provide them with the support that they need (Han, Ota, \& Kwon, 2016). ICR consists of two domains: "Cause" and "Result" (Han, Ota, \& Kwon, 2016). The cause domain includes the "Physical" and "Mental" subdomains. The "Physical" subdomain consists of "Body condition" and "Posture, movement, and motion" while the "Mental" domain consists of "Inattention" "Hyperactivity/impulsivity", "Adherence", and "Self-esteem" (Han, Ota, \& Kwon, 2016). The "Result" domain, on the other hand, includes the "Daily living" and "Learning" subdomains. The "Daily living" subdomain consists of "Social functioning" and "Communication" while the "Learning" subdomain consists of "Listening", "Speaking", "Reading", "Writing", "Calculating", and "Reasoning" (Han, Ota, \& Kwon, 2016).

In total, ICR consists of 82 items (Han, Ota, \& Kwon, 2016). The scores are given based on a 5 -point scale, where $1=$ strongly agree; $2=$ agree; $3=$ neutral; $4=$ disagree; and $5=$ strongly disagree (Han, Ota, \& Kwon, 2016). The scores are added by subdomain; as the score of the subdomain is lower, the needs of the subdomain are stronger (Han, Ota, $\&$ Kwon, 2016). To determine if the child is an IN-Child, the cutoff value was set as shown in Table 1 (Han, Yano, Kohara, et al., 2017). ICR is a tool whose reliability and validity have been tested in the precedent study (Han, Yano, Kohara, et al., 2017). 
Table 1. Cutoff value of ICR

\begin{tabular}{lc}
\hline \multicolumn{1}{c}{ Domains } & $\begin{array}{c}\text { Cutoff value/ } \\
\text { Domain score }\end{array}$ \\
\hline Total score & $307 / 410$ \\
Body Condition & $41 / 50$ \\
Posture, Movement, and Motion & $41 / 50$ \\
Inattention & $18 / 35$ \\
Hyperactivity/Impulsivity & $21 / 30$ \\
Adherence & $21 / 30$ \\
Self-esteem & $17 / 25$ \\
Social Functioning & $18 / 25$ \\
Communication & $17 / 25$ \\
Listening & $16 / 25$ \\
Speaking & $17 / 25$ \\
Reading & $17 / 25$ \\
Writing & $16 / 25$ \\
Calculating & $13 / 25$ \\
Reasoning & $8 / 15$ \\
\hline & Cutoff value $=$ Average score-2SD \\
Source: Author-modified, Han, Yano, Kohara, et al., 2017.
\end{tabular}

\section{Correspondence between ICR and the Medical Diagnostic Criteria}

DSM- 5 was used for the medical diagnostic criteria. By analyzing the correspondence between DSM- 5 and ICR, the missing items in ICR were added to the new tool.

This study targeted autism spectrum disorder (ASD) and attention deficit/hyperactivity disorder (ADHD) among the neurodevelopmental disorders of DSM- 5 for the creation of a new tool. It has been reported that in schools, there are many children with a specific learning disorder (SLD) as well as with ASD and ADHD (MEXT, 2012). As there are no clear diagnosis criteria in DSM-5, however, for which reason the missing data were included in the new tool (APA, 2013), SLD was excluded from the target disorders of the new tool.

DSM- 5 provides criteria for diagnosing ASD, such as the social communication and repetitive patterns of behavior, interests, and activities (APA, 2013), which are analyzed as corresponding to the "Adherence" and "Communication" domains of ICR.

\section{Data Analysis Based on the Survey through ICR}

\subsection{Subjects and procedure}

A survey was conducted among the children attending elementary and middle schools in Okinawa Prefecture. Before the survey, a letter signed by the principal explaining the purpose and anonymity of the survey was sent to the parents; the parents were also notified that they would not be disadvantaged by their non-participation in the survey, and that the anonymization of the survey ensured that the children's data could not be revealed. Finally, the survey was conducted among the children whose parents agreed to their participation in this study. It was conducted by the homeroom teachers between February and March 2017, using ICR, with 624 students from one elementary school and 504 students from one middle school participating. 


\subsection{Analysis}

\subsubsection{Definition of children with ASD and ADHD tendencies}

ASD and ADHD tendencies need to be defined to analyze the data of the children who showed similar characteristics through ICR. Even though ICR is not a tool for medical purposes, it has common domains with DSM-5. In this study, the children whose scores for the "Adherence" and "Communication" domains of ICR were below the cutoff values were categorized as children with ASD tendencies, and the children whose scores for the "Inattention" and "Hyperactivity/ impulsivity" domains of ICR were below the cutoff values were categorized as children with ADHD tendencies.

\subsubsection{Correlation analysis}

Correlation analysis was conducted to collect the data of the children with ASD and ADHD tendencies through ICR; the correlations among the items in the "Adherence" and "Communication" subdomains of ICR were analyzed using the data of the children with ASD tendencies, and the correlations among the items in the "Inattention" and "Hyperactivity/ impulsivity" subdomains of ICR were analyzed using the data of the children with ADHD tendencies.

\subsubsection{Test of reliability}

The reliability of the data collected through the survey, using ICR, was tested. To test the reliability, the internal consistency was measured with Cronbach's a. As the Cronbach's a value was close to 1 , it is considered more reliable; the scale with a value higher than 0.700 is considered reliable (Cronbach, 1951).

\subsubsection{Statistical analysis}

Statistical analysis was conducted through SPSS (IBM SPSS Statistics ver.23). The significance level was $\mathrm{p}<0.05$.

\section{Results}

\section{Correspondence Analysis between ICR and DSM-5}

Consistency analysis was conducted among the items of ICR and DSM-5. The analysis results related to ASD and ADHD are shown in Table 2 and 3, respectively. The diagnostic criteria of ASD are covered by DSM-5, and the social communication domains are covered by the items of ICR. Among the social functioning items of ICR, Q47, Q48, and Q49 corresponded with the criteria of DSM-5. No items in ICR, however, corresponded with the items of "Stereotyped or repetitive motor movements, use of objects, or speech" and "Hyper- or hypo-reactivity to sensory input or unusual interests in sensory aspects of the environment "in the "Repetitive movement" domain of DSM-5. 
No item in ICR corresponded with the items of "Often has trouble holding his/her attention on tasks or play activities" and "Often loses things necessary for tasks and activities" in the "Inattention"domain of DSM-5, which are related to the diagnosis of ADHD. In addition, no item in ICR corresponded with the items of "Often unable to play or take part in leisure activities quietly","Is often "on the go," acting as if "driven by a motor" " and "Often talks excessively" in the "Hyperactivity/impulsivity" domain in

DSM-5.

Table 2. Correspondence between DSM-5 and ICR (ASD)

\begin{tabular}{|c|c|c|}
\hline \multicolumn{2}{|r|}{ DSM-5 } & ICR \\
\hline \multirow{3}{*}{$\begin{array}{l}\text { A. Persistent } \\
\text { deficits in } \\
\text { social } \\
\text { communication } \\
\text { and social } \\
\text { interaction } \\
\text { across multiple } \\
\text { contexts, as } \\
\text { manifested by } \\
\text { the following, } \\
\text { currently or by } \\
\text { history }\end{array}$} & $\begin{array}{l}\text { (1) Deficits in social-emotional reciprocity, } \\
\text { ranging, for example, from abnormal social } \\
\text { approach and failure of normal back-and-forth } \\
\text { conversation; to reduced sharing of interests, } \\
\text { emotions, or affect; to failure to initiate or } \\
\text { respond to social interactions. }\end{array}$ & $\begin{array}{l}\text { Q48 "Sometimes tells something unrelated } \\
\text { to the conversation for no purpose" } \\
\text { Q50 "Does not try to interact with others } \\
\text { during the class" } \\
\text { Q51 "Sometimes says something to others } \\
\text { out of context" }\end{array}$ \\
\hline & $\begin{array}{l}\text { (2) Deficits in nonverbal communicative } \\
\text { behaviors used for social interaction, ranging, for } \\
\text { example, from poorly integrated verbal and } \\
\text { nonverbal communication; to abnormalities in } \\
\text { eye contact and body language or deficits in } \\
\text { understanding and use of gestures; to a total lack } \\
\text { of facial expressions and nonverbal } \\
\text { communication. }\end{array}$ & $\begin{array}{l}\text { Q52 "Sometimes talks in an awkward or } \\
\text { peculiar way, without intonation and a } \\
\text { sense of timing; talk is not appropriate" } \\
\text { Q54 "Sometimes cannot choose the } \\
\text { appropriate way of communicating" }\end{array}$ \\
\hline & $\begin{array}{l}\text { (3) Deficits in developing, maintaining, and } \\
\text { understanding relationships, ranging, for } \\
\text { example, from difficulties adjusting behavior to } \\
\text { suit various social contexts; to difficulties in } \\
\text { sharing imaginative play or in making friends; to } \\
\text { absence of interest in peers. }\end{array}$ & $\begin{array}{l}\text { Q47 "Cannot cooperate with his/her friends } \\
\text { when playing" } \\
\text { Q49 "Plays alone even if his/her friends are } \\
\text { nearby" } \\
\text { Q53 "Cannot understand sarcasm or irony" }\end{array}$ \\
\hline \multirow{4}{*}{$\begin{array}{l}\text { B. Restricted, } \\
\text { repetitive } \\
\text { patterns of } \\
\text { behavior, } \\
\text { interests, or } \\
\text { activities, as } \\
\text { manifested by } \\
\text { at least two of } \\
\text { the following, } \\
\text { currently or by } \\
\text { history }\end{array}$} & $\begin{array}{l}\text { (1) Stereotyped or repetitive motor movements, } \\
\text { use of objects, or speech }\end{array}$ & \\
\hline & $\begin{array}{l}\text { (2) Insistence on sameness, inflexible adherence } \\
\text { to routines, or ritualized patterns or verbal } \\
\text { nonverbal behavior }\end{array}$ & $\begin{array}{l}\text { Q34 "Is obsessed with specific objects" } \\
\text { Q38 "Has a peculiar daily routine and hates } \\
\text { changes" } \\
\text { Q39 "Sometimes cannot perform simple } \\
\text { daily activities as he/she is obsessed by } \\
\text { specific actions and ideas" }\end{array}$ \\
\hline & $\begin{array}{l}\text { (3) Highly restricted, fixated interests that are } \\
\text { abnormal in intensity or focus }\end{array}$ & $\begin{array}{l}\text { Q35 "While extremely good at doing } \\
\text { something, is extremely bad at other } \\
\text { things" } \\
\text { Q36 "Shows knowledge of a specific field } \\
\text { but does not understand its meaning due to } \\
\text { rote memorization" } \\
\text { Q37 "Is not interested in what other } \\
\text { children are usually interested in, and has } \\
\text { his/her own world of knowledge of specific } \\
\text { subjects" }\end{array}$ \\
\hline & $\begin{array}{l}\text { (4) Hyper- or hypo-reactivity to sensory input or } \\
\text { unusual interests in sensory aspects of the } \\
\text { environment }\end{array}$ & \\
\hline
\end{tabular}


Table 3. Correspondence between DSM- 5 and ICR (ADHD)

\begin{tabular}{|c|c|c|c|}
\hline \multicolumn{3}{|c|}{ DSM-5 } & ICR \\
\hline \multirow{18}{*}{$\begin{array}{l}\text { A. People with ADHD } \\
\text { show a persistent } \\
\text { pattern of inattention } \\
\text { and/or } \\
\text { hyperactivity-impulsivity } \\
\text { that interferes with } \\
\text { functioning or } \\
\text { development }\end{array}$} & \multirow{9}{*}{$\begin{array}{l}\text { (1) Inattention: Six or } \\
\text { more symptoms of } \\
\text { inattention for children } \\
\text { up to age } 16 \text {, or five or } \\
\text { more for adolescents } 17 \\
\text { and older and adults; } \\
\text { symptoms of inattention } \\
\text { have been present for at } \\
\text { least } 6 \text { months, and they } \\
\text { are inappropriate for } \\
\text { developmental level }\end{array}$} & $\begin{array}{l}\text { (a) Often fails to give close } \\
\text { attention to details or } \\
\text { makes careless mistakes in } \\
\text { schoolwork, at work, or } \\
\text { with other activities }\end{array}$ & $\begin{array}{l}\text { Q23 "Often fails to give } \\
\text { close attention to details or } \\
\text { makes careless mistakes } \\
\text { in schoolwork, at work, or } \\
\text { with other activities." }\end{array}$ \\
\hline & & $\begin{array}{l}\text { (b) Often has trouble } \\
\text { holding attention on tasks } \\
\text { or play activities }\end{array}$ & \\
\hline & & $\begin{array}{l}\text { (c) Often does not seem to } \\
\text { listen when spoken to } \\
\text { directly }\end{array}$ & $\begin{array}{l}\text { Q24 "Often does not seem } \\
\text { to listen when spoken to } \\
\text { directly" }\end{array}$ \\
\hline & & $\begin{array}{l}\text { (d) Often does not follow } \\
\text { through on instructions } \\
\text { and fails to finish } \\
\text { schoolwork, chores, or } \\
\text { duties in the workplace }\end{array}$ & $\begin{array}{l}\text { Q27 "Often does not follow } \\
\text { through on instructions } \\
\text { and fails to finish } \\
\text { schoolwork, chores, or } \\
\text { duties in the workplace" }\end{array}$ \\
\hline & & $\begin{array}{l}\text { (e) Often has trouble } \\
\text { organizing tasks and } \\
\text { activities }\end{array}$ & $\begin{array}{l}\text { Q26 "Often has trouble } \\
\text { organizing tasks and } \\
\text { activities" }\end{array}$ \\
\hline & & $\begin{array}{l}\text { (f) Often avoids, dislikes, or } \\
\text { is reluctant to do tasks } \\
\text { that require mental effort } \\
\text { over a long period of time }\end{array}$ & $\begin{array}{l}\text { Q25 "Often avoids, } \\
\text { dislikes, or is reluctant to } \\
\text { do tasks that require } \\
\text { mental effort over a long } \\
\text { period of time" }\end{array}$ \\
\hline & & $\begin{array}{l}\text { (g) Often loses things } \\
\text { necessary for tasks and } \\
\text { activities }\end{array}$ & \\
\hline & & $\begin{array}{l}\text { (h) Is often easily } \\
\text { distracted }\end{array}$ & $\begin{array}{l}\text { Q21 "Is often easily } \\
\text { distracted" }\end{array}$ \\
\hline & & $\begin{array}{l}\text { (i) Is often forgetful in daily } \\
\text { activities }\end{array}$ & $\begin{array}{l}\text { Q22 "Is often forgetful in } \\
\text { daily activities" }\end{array}$ \\
\hline & \multirow{9}{*}{$\begin{array}{l}\text { (2) Hyperactivity and } \\
\text { Impulsivity: Six or more } \\
\text { symptoms of } \\
\text { hyperactivity-impulsivity } \\
\text { for children up to age } 16 \text {, } \\
\text { or five or more for } \\
\text { adolescents } 17 \text { and older } \\
\text { and adults; symptoms of } \\
\text { hyperactivity-impulsivity } \\
\text { have been present for at } \\
\text { least } 6 \text { months to an } \\
\text { extent that is disruptive } \\
\text { and inappropriate for the } \\
\text { person's developmental } \\
\text { level }\end{array}$} & $\begin{array}{l}\text { (a) Often fidgets with or } \\
\text { taps hands or feet, or } \\
\text { squirms in seat }\end{array}$ & $\begin{array}{l}\text { Q28 "Often fidgets or taps } \\
\text { his/her hands or feet, or } \\
\text { squirms in his/her seat" }\end{array}$ \\
\hline & & $\begin{array}{l}\text { (b) Often leaves seat in } \\
\text { situations when remaining } \\
\text { seated is expected }\end{array}$ & $\begin{array}{l}\text { Q29 "Often leaves his/her } \\
\text { seat in situations when } \\
\text { remaining seated is } \\
\text { expected" }\end{array}$ \\
\hline & & $\begin{array}{l}\text { (c) Often runs about or } \\
\text { climbs in situations where } \\
\text { it is not appropriate }\end{array}$ & $\begin{array}{l}\text { Q30 "Often runs about or } \\
\text { climbs in situations where } \\
\text { it is not appropriate" }\end{array}$ \\
\hline & & $\begin{array}{l}\text { (d) Often unable to play or } \\
\text { take part in leisure } \\
\text { activities quietly }\end{array}$ & \\
\hline & & $\begin{array}{l}\text { (e) Is often "on the go" } \\
\text { acting as if "driven by a } \\
\text { motor" }\end{array}$ & \\
\hline & & (f) Often talks excessively & \\
\hline & & $\begin{array}{l}\text { (g) Often blurts out an } \\
\text { answer before a question } \\
\text { has been completed }\end{array}$ & $\begin{array}{l}\text { Q32 "Often blurts out an } \\
\text { answer before the question } \\
\text { has been completed" }\end{array}$ \\
\hline & & $\begin{array}{l}\text { (h) Often has trouble } \\
\text { waiting his/her turn }\end{array}$ & $\begin{array}{l}\text { Q31 "Often has trouble } \\
\text { waiting for his/her turn" }\end{array}$ \\
\hline & & $\begin{array}{l}\text { (i) Often interrupts or } \\
\text { intrudes on others }\end{array}$ & $\begin{array}{l}\text { Q33 “Often interrupts or } \\
\text { intrudes on others' } \\
\text { businesses" }\end{array}$ \\
\hline
\end{tabular}




\section{Data Analysis Based on the Survey Results through ICR}

Among the collected data of 1,131 children from one elementary school and one junior high school, the data of 1,059 children were analyzed. The sociodemographic data of the children are shown in Table 4.

Table 4. Characteristics of the study subjects

\begin{tabular}{lll}
\hline Total $(\mathrm{n}=1,059)$ & & \\
\hline Elementary school $(\mathrm{n}=594)$ & & \\
Sex & Male & $290(48.8)$ \\
& Female & $304(51.2)$ \\
Grade & 1 & $103(17.3)$ \\
& 2 & $98(16.5)$ \\
& 3 & $103(17.3)$ \\
& 4 & $89(15.0)$ \\
& 5 & $100(16.8)$ \\
Junior high school $(\mathrm{n}=465)$ & 6 & $101(17.0)$ \\
Sex & & \\
& Male & $235(50.5)$ \\
Grade & Female & $230(49.5)$ \\
& 1 & $231(49.7)$ \\
& 2 & $234(50.3)$ \\
\hline
\end{tabular}

\subsection{ICR scores and reliability coefficient}

The ICR scores are shown in Table 5. The internal consistency test results through Cronbach's a are shown in Table 5.

Table 5. ICR score and Cronbach's a

\begin{tabular}{lccc}
\hline \multicolumn{1}{c}{ Domains (full score) } & Mean & SD & Cronbach's a \\
\hline Body condition (50) & 48.57 & 3.51 & .846 \\
Posture, movement, and motion (50) & 48.66 & 3.81 & .898 \\
Inattention (35) & 31.05 & 6.52 & .942 \\
Hyperactivity/impulsivity (30) & 28.50 & 3.63 & .895 \\
Adherence (30) & 28.47 & 3.54 & .896 \\
Self-esteem (25) & 23.50 & 2.94 & .853 \\
Social functioning (25) & 23.78 & 2.65 & .786 \\
Communication (25) & 23.62 & 3.00 & .849 \\
Listening (25) & 23.17 & 3.56 & .916 \\
Speaking (25) & 23.56 & 3.20 & .920 \\
Reading (25) & 23.54 & 3.26 & .938 \\
Writing (25) & 23.29 & 3.62 & .923 \\
Calculating (25) & 22.61 & 4.50 & .962 \\
Reasoning (15) & 13.67 & 2.60 & .962 \\
\hline
\end{tabular}

\subsection{Data analysis related to ASD}

According to the cutoff values, the data of the children whose scores for "Adherence" were below 21 and whose scores for "Communication" were below 17 were extracted. Such children numbered 34 in all (3.21\%). In the results, the data of $26(76.5 \%)$ out of the 34 children were analyzed. Their average age was $11.44 \pm 2.13$. 


\subsection{Data analysis related to $A D H D$}

According to the cutoff values, the data of the children whose scores for "Inattention"were below 18 and whose scores for "Hyperactivity/impulsivity" were below 21 were extracted. Such children numbered 38 in all. In the results, the data of 32 $(84.2 \%)$ out of the 38 children (3.58\%) were analyzed. Their average age was $11.24 \pm 2.22$.

\subsection{Correlation analysis}

The results of the correlation analysis of the ICR items related to ASD tendencies are shown in Table 6. It was found that Q35, Q38, Q39, Q41, and Q51 are correlated with the "Adherence" and "Communication"domains of ICR, as the ASD-related items.

Table 6. Correlation analysis of ICR in children with ASD tendencies

\begin{tabular}{lccccc}
\hline Domains & Q35 & Q38 & Q39 & Q41 & Q51 \\
\hline Adherence & $.392^{*}$ & $.530^{* *}$ & $.642^{* *}$ & $.459^{* *}$ & $.348^{*}$ \\
Communication & $.374^{*}$ & $.447^{* *}$ & $.369^{* *}$ & $.350^{*}$ & $.504^{* *}$ \\
\hline
\end{tabular}

The results of the correlation analysis of the ICR items related to ADHD tendencies are shown in Table 7. It was found that Q21, Q27, Q33, Q47, and Q51 are correlated with the "Inattention"and "Hyperactivity/impulsivity"domains of ICR, as the ADHD-related items.

Table 7. Correlation analysis of ICR in children with ADHD tendencies

\begin{tabular}{lllll}
\hline \multicolumn{1}{c}{ Domains } & Q21 & Q27 & Q33 & Q47 \\
\hline Inattention & $.388^{*}$ & $.458^{* *}$ & $.359^{*}$ & $.416^{* *}$ \\
Hyperactivity/impulsivity & $.398^{*}$ & $.396^{*}$ & $.640^{* *}$ & $.383^{*}$ \\
\hline
\end{tabular}

\section{Discussion}

As aforementioned, this study aimed to develop a tool that would enable collaboration between the fields of medicine and education based on ICR, for the facilitation of medical diagnosis and the provision of continuous educational support for children with developmental disorders.

In this study, the correspondence between ICR and DSM-5 was analyzed for ASD and ADHD. There exist items in ICR that correspond with "Stereotyped or repetitive motor movements, use of objects, or speech" and "Hyper- or hypo-reactivity to sensory input or unusual interests in sensory aspects of the environment", which are the criteria for ASD in DSM-5. "Repetitive motor movement, use of object, or speech" are the representative characteristics of ASD (APA, 2013). Sensory difficulty is one of the characteristics that children with ASD show most frequently (Schaaf \& Case-Smith, 
2014). Furthermore, as children with hypoesthesia and/or hyperesthesia refuse to touch other persons and objects, they become poor at verbally reporting their perceptions through their sense of touch, which obstructs their communication (Chikai \& Miyake, 2014). Therefore, children with hypoesthesia and/or hyperesthesia need to be distinguished from those without these conditions, and it was for this reason that the items related to repetitive movement and the senses were included in the new tool.

Three items in the social functioning domain correspond to the social communication ability of ASD patients in DSM-5. Including these items, ICR covers many of the ASD criteria in DSM-5, but the number of items for assessing the social communication ability of children with ASD tendencies needs to increase to enable the conditions of such children to be understood better. It is effective to intervene in the treatment of children with ASD who have difficulty communicating by detecting it in its early stage (Lai, Lombardo, \& Baron-Cohen, 2014). From this perspective, the social communication ability of children with ASD needs to be dealt with more specifically and comprehensively at the same time. Therefore, the three items related to the social communication ability of ASD patients and that correspond to the social functioning domain in ICR were included in the new tool.

Likewise, for the ADHD criteria, the items in DSM- 5 that are not in ICR were also added, such as "Often has trouble holding his/her attention on tasks or play activities" and "Often loses things necessary for tasks and activities" in the "Inattention" domain and "Often unable to play or take part in leisure activities quietly", "Is often "on the go," acting as if "driven by a motor"', and "Often talks excessively" in the "Hyperactivity/impulsivity" domain.

Through the aforementioned process, the items for the new tool were collected based on ICR. As for ASD, six items were added to the "Adherence" and "Communication" domains in ICR, which made the items in those domains total 17. Likewise, for ADHD, five items were added to the "Inattention" and "Hyperactivity/impulsivity" domains, which made the items in those domains total 19. The final version of the new tool is shown in Appendix.

Through this study, a new tool was made, but its reliability and validity have yet to be verified. The verification of the reliability and validity of the new tool by professionals from the fields of medicine and education has been left as the future research task. Furthermore, the data that need to be collected through the tool that was used to test the contents' validity and reliability and the construct validity also need to be verified.

The new tool that was created through this study will be the common tool between the fields of medicine and education as well as the only means to provide medical specialists with the information on children who need to undergo medical examination, and is also expected to be a useful tool for both the medical diagnosis of developmental disorders and the provision of educational support for children with difficulties due to their developmental disorders. 


\section{References}

1) American Psychiatric Association (2013) Diagnostic and statistical manual of mental disorders (DSM-5®): American Psychiatric Pub.

2) Ministry of Internal Affairs and Communications (2017) Recommendation based on administrative evaluation / monitoring result on support for people with developmental disabilities (in Japanese).

3) Ministry of Education, Culture, Sports, Science and Technology (2012) A survey on students who need special educational support due to suspected developmental disorders in regular classes (in Japanese).

4) Han CW, Ota M, Kwon HJ (2016) Development of the IN-Child (Inclusive Needs Child) Record. Total Rehabilitation Research, 3, 84-99.

5) Han CW, Yano N, Kohara A, Kwon HJ, Ota M, Tanaka A (2017) The Verification of the Reliability and Construct Validity of the IN-Child Record: Analysis of Cross-sectional Data、Total Rehabilitation Research, 5, 1-14.

6) Cronbach LJ (1951) Coefficient alpha and the internal structure of tests. Psychometrika, 16, 297-334.

7) Schaaf RC \& Case-Smith J (2014) Sensory interventions for children with autism. Journal of Comparative Effectiveness Research, 3(3), 225-227.

8) Chikai M \& Miyake H (2014) Development of a Haptic Performance Diagnostics Device for Children with Developmental Disorder. The Japanese journal of medical instrumentation, 84(1), 18-22.

9) Lai MC, Lombardo MV, Baron-Cohen S (2014) Autism. Lancet, 383, 896-910.

10) Staikova E, Gomes H, Tartter V, McCabe A, Halperin JM (2013) Pragmatic deficits and social impairment in children with ADHD. The Journal of Child Psychology and Psychiatry, 54(12), 1275-1283. 


\section{Appendix}

\section{Sheet 1}

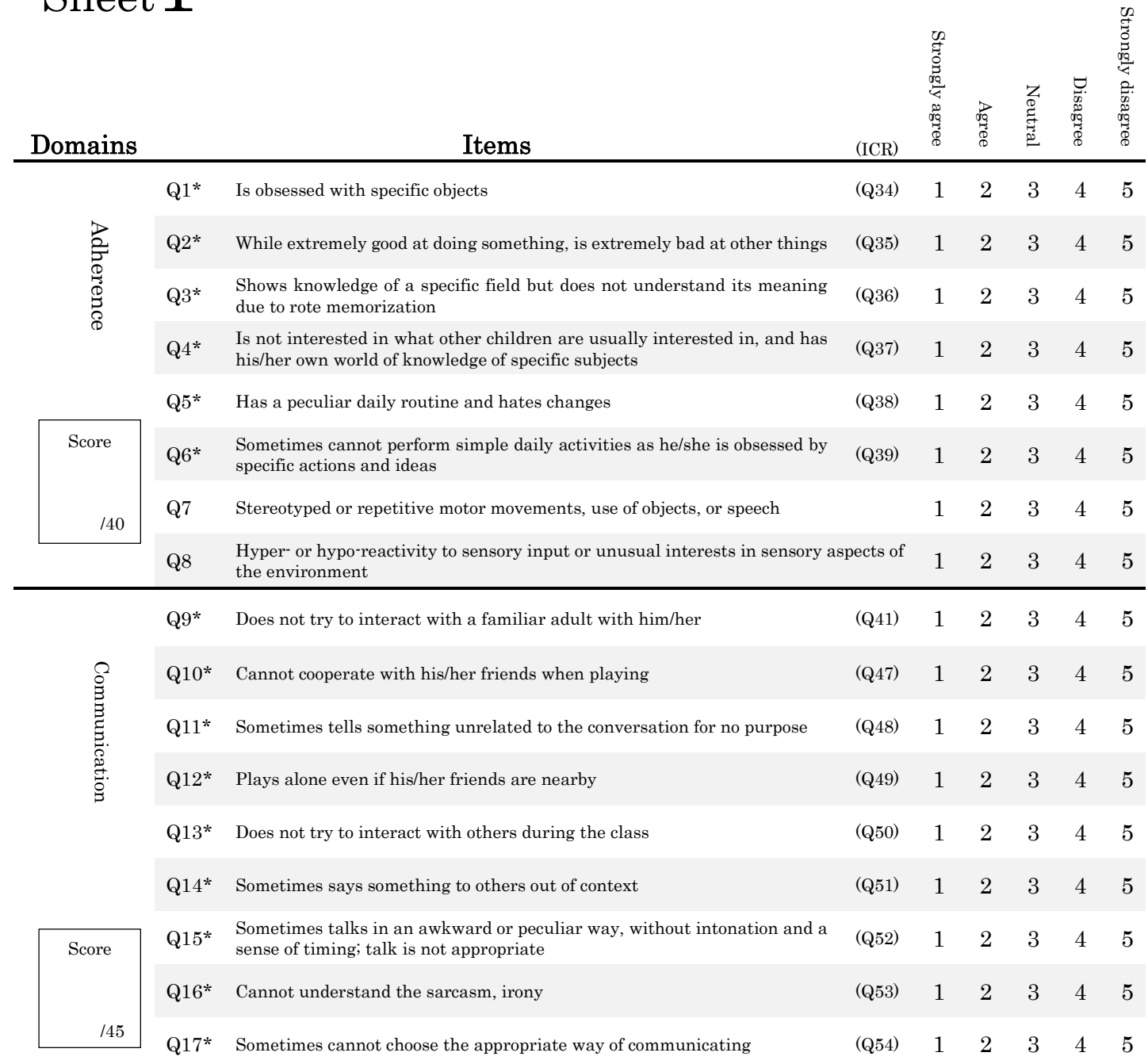




\section{Sheet 2}

\begin{tabular}{|c|c|c|c|c|c|c|c|c|}
\hline Domains & & Items & $(\mathrm{ICR})$ & 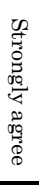 & 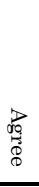 & 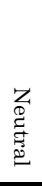 & 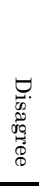 & 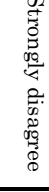 \\
\hline \multirow{6}{*}{ 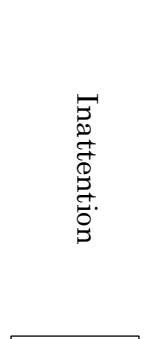 } & Q18* & Is often easily distracted & (Q21) & 1 & 2 & 3 & 4 & 5 \\
\hline & Q19* & Is often forgetful in daily activities & (Q22) & 1 & 2 & 3 & 4 & 5 \\
\hline & $\mathrm{Q} 20^{*}$ & $\begin{array}{l}\text { Often fails to give close attention to details or makes careless mistakes in } \\
\text { schoolwork, at work, or with other activities }\end{array}$ & (Q23) & 1 & 2 & 3 & 4 & 5 \\
\hline & $\mathrm{Q} 21^{*}$ & Often does not seem to listen when spoken to directly & (Q24) & 1 & 2 & 3 & 4 & 5 \\
\hline & $\mathrm{Q} 22^{*}$ & $\begin{array}{l}\text { Often avoids, dislikes, or is reluctant to do tasks that require mental effort } \\
\text { over a long period of time }\end{array}$ & (Q25) & 1 & 2 & 3 & 4 & 5 \\
\hline & Q23* & Often has trouble organizing tasks and activities & (Q26) & 1 & 2 & 3 & 4 & 5 \\
\hline \multirow[t]{3}{*}{ Score } & $\mathrm{Q} 24 *$ & $\begin{array}{l}\text { Often does not follow through on instructions and fails to finish schoolwork, } \\
\text { chores, or duties in the workplace }\end{array}$ & (Q27) & 1 & 2 & 3 & 4 & 5 \\
\hline & Q25 & Often has trouble holding attention on tasks or play activities & & 1 & 2 & 3 & 4 & 5 \\
\hline & Q26 & Often loses things necessary for tasks and activities & & 1 & 2 & 3 & 4 & 5 \\
\hline \multirow{6}{*}{ 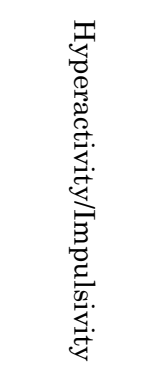 } & $\mathrm{Q} 27 *$ & Often fidgets with or taps hands or feet, or squirms in seat & (Q28) & 1 & 2 & 3 & 4 & 5 \\
\hline & $\mathrm{Q} 28^{*}$ & Often leaves seat in situations when remaining seated is expected & (Q29) & 1 & 2 & 3 & 4 & 5 \\
\hline & Q29* & Often runs about or climbs in situations where it is not appropriate & (Q30) & 1 & 2 & 3 & 4 & 5 \\
\hline & Q30* & Often has trouble waiting his/her turn & (Q31) & 1 & 2 & 3 & 4 & 5 \\
\hline & Q31* & Often blurts out an answer before a question has been completed & (Q32) & 1 & 2 & 3 & 4 & 5 \\
\hline & $\mathrm{Q} 32 *$ & Often interrupts or intrudes on others & (Q33) & 1 & 2 & 3 & 4 & 5 \\
\hline \multirow{2}{*}{ Score } & Q33* & Often unable to play or take part in leisure activities quietly & & 1 & 2 & 3 & 4 & 5 \\
\hline & Q34 & Is often "on the go" acting as if "driven by a motor & & 1 & 2 & 3 & 4 & 5 \\
\hline 145 & Q35 & Often talks excessively & & 1 & 2 & 3 & 4 & 5 \\
\hline
\end{tabular}


Asian Society of HUMAN SERVICES

- Editorial Board -

Editor-in-Chief Masahiro KOHZUKI
Executive Editors $\quad$ Injae LEE
Satoru EBIHARA
University of the Ryukyus (Japan)
Changwan HAN
University of the Ryukyus (Japan)
Guo QI
Tianjin Medical University (China)
Hideyuki OKUZUMI
Tokyo Gakugei University (Japan)
Hsintai LIN
National Taiwan Noraml University (Taiwan)
Inkeri Ruokonen
University of Helsinki (Finland)
Jaewon LEE
Pukyong National University (Korea)
Jenyi LI
Nanyang Technological University (Singapore)
Jung Won Sonn
University College London (UK)
Tohoku University (Japan)
Hanshin Univerisity (Korea)
Toho University (Japan)

\author{
Kagari SHIBAZAKI \\ University of Huddersfield (UK) \\ Nigel A Marshall \\ University of Sussex (UK) \\ Osamu ITO \\ Tohoku University (Japan) \\ Taku HARADA \\ Tohoku University (Japan) \\ Petr Dobšák \\ Masaryk University (Czech) \\ Sunwoo LEE \\ Inje University (Korea) \\ Taekyun YOO \\ Soongsil University (Korea) \\ Youngchoul KIM \\ University of Evansville (USA) \\ Yuichiro HARUNA \\ National Institute of Vocational Rehabilitation (Japan) \\ Zhongli JIANG \\ First Affiliated Hospital of Nanjing Medical \\ University (China)
}

\title{
Editorial Staff
}

- Editorial Assistants

Aiko KOHARA
Marcus Eije Zantere
Moonjung KIM

Natsuki YANO
University of the Ryukyus (Japan)

University of Gothenburg (Sweden)

Korea Labor Force Development Institute for the aged (Korea)

Tohoku University (Japan)

\section{Asian Journal of Human Services VOL.13 October 2017}

() 2017 Asian Society of Human Services

Editor-in-Chief Masahiro KOHZUKI

Presidents Masahiro KOHZUKI $\cdot$ Sunwoo LEE

Publisher Asian Society of Human Services

Faculty of Education, University of the Ryukyus, 1 Senbaru, Nishihara, Nakagami, Okinawa, Japan FAX: +81-098-895-8420 E-mail: ashs201091@gmail.com

Production 


\section{Asian Journal of Human Services}

VOL.13 October 2017

CONTENTS

\section{ORIGINAL ARTICLES}

Male Caregivers Get Coping to Nursing care with Dementia Living at Home

Midori NISHIO et al., 1

Study on Triage Education for Nursing Students: Analysis of Their Errors in Triage

Kazuyuki AKINAGA et al., 10

The Role of Surgical Nurse in International Disaster Response (IDR) in Japan

: Recognition of the Medical Workers with Experience in IDR

Akina ISHIBASHI et al., 23

Objective and Subjective Evaluation of Neurofeedback Trainings in Nonclinical Individuals

Kota SUZUKI et al., 36

Life Satisfaction and Social Capital of the Chinese Elderly

Xinyu HE et al., 46

Development of a Tool for Collaboration between the Fields of Medicine and Education Based on

"Inclusive Needs-Child Record": With Focus on Autism Spectrum Disorder (ASD) and Attention

Deficit/Hyperactivity Disorder (ADHD)

Natsuki YANO et al., 63

CASE REPORT

Individual Evaluation of the Visual Functions of Children with Severe Motor and Intellectual

Disabilities using the Heart Rate Index

Published by

Asian Society of Human Services

Okinawa, Japan 